medical care, with less danger from cancer of the cervix, than any other group of women.

We wish to acknowledge the programming assistance received from Mrs. M. A. K. Angell and Mrs. Jane Meikle.

Mrs. Joyce Washington was responsible for the efficient manner in which this study was carried through at all of the separate centres of Planned Parenthood of New York City, Inc.

We thank Mr. Alfred F. Moran, executive director of Planned Parenthood of New York City, Inc., and Dr. Sherwin A. Kaufman, medical director, for their assistance and support.

Dr. Christopher Tietze critically reviewed much of the data with us and contributed many helpful suggestions.

The many centre directors, physicians, nurses, and particularly the dedicated young women who helped collect and record data deserve special commendation for their role in this study, and we regret that they cannot be individually recognized.

\section{REFERENCES}

Aitken-Swan, J., and Baird, D. (1965). British fournal of Cancer, 19, 217.

Allen, E., and Gardner, W. U. (1941). Cancer Research, 1, 359.

Boyd, J.'T., and Doll, R. (1964). British fournal of Cancer, 18, 419.
Christopherson, W. M., and Parker, J. E. (1965). New England fournal of Medicine, 273, 235

Dubrow, H., Melamed, M. R., Flehinger, B., Kelisky, R., and Koss, L. G. (1969). Obstetric and Gynecological Survey. In press.

Gagnon, F. (1950). American fournal of Obstetrics and Gynecology, $60,516$.

Haenszel, W., and Hillhouse, M. (1959). Fournal of the National Cancer Institute, 22, 1157

Jones, E. G., MacDonald, I., and Breslow, L. (1958). American fournal of Obstetrics and Gynecology, 76, 1.

Koss, L. G. (1968). Diagnostic Cytology and Its Histopathologic Bases, 2nd ed. Phiadelphia, Lippincott.

Koss, L. G., Stewart, F. W., Foote, F. W. Jordan, M. J., Bader, G. M. and Day, E. (1963). Cancer (Philadelphia), 16, 1160

Lombard, H. L. and Potter, E. A. (1950). Cancer (Philadelphia), 3, 960. Marshall, C. E. (1965). Cancer (Philadelphia), 18, 153.

Pratt-Thomas, H. R., Heins, H. C., Latham, E., Dennis, E. J., and McIver, F. A. (1956) Cancer (Philadephia), 9, 671.

Røjel, J. (1953). Acta Pathologica et Microbiologica Scandinavica, Suppl.

Rotkin, I. D. (1962). Fournal of the American Medical Association, 179,

Rotkin, I. D., and King, R. W. (1962). American fournal of Obstetrics and Gynecology, 83, 720 .

Taylor, H. B., Irey, N. S., and Norris, H. J. (1967). fournal of the American Medical Association, 202, 637.

Terris, M., and Oalmann, M. C. (1960). Fournal of the American Medical Association, 174, 1847.

Wynder, E. L., Cornfield, J., Schroff, P. D., and Doraiswami, K. R. (1954). American fournal of Obstetrics and Gynecology, 68, 1016.

\title{
Results of Treatment of Thyrotoxicosis after Postoperative Relapse
}

\author{
D. G. MCLARTY,* M.B., CH.B. ; W. D. ALEXANDER, † M.D., F.R.C.P.ED. ; R. MCG. HARDEN, $\ddagger$ M.R.C.P.GLASG. \\ D. H. CLARK,§ M.D., CH.M., F.R.C.S.
}

British Medical fournal, 1969, 3, 200-203

\begin{abstract}
Ummary : Ninety patients who had a recurrence of thyrotoxicosis after thyroidectomy have been reviewed. All 10 patients who had a second operation and 18 out of 20 patients treated with a full course of antithyroid drugs relapsed. These results differ greatly from the results of treatment of the first episode of thyrotoxicosis, whether by thyroidectomy or antithyroid drugs. Radioiodine is the treatment of choice in this group of patients, despite the high incidence of hypothyroidism.
\end{abstract}

\section{Introduction}

Most follow-up studies of patients treated by thyroidectomy make reference to the incidence of recurrence of thyrotoxicosis after operation. The prognosis for such relapsed patients with reference to subsequent morbidity and to the effectiveness of subsequent treatment is, however, uncertain. This study describes the results of treatment in 90 patients who relapsed after thyroidectomy. In this situation the results of treatment by drugs and surgery are very different from those of treatment of the first episode.

\section{Methods}

Ninety patients $(77(85.6 \%)$ female and $13(14.4 \%)$ male) who had been treated by thyroidectomy for thyrotoxicosis and who had subsequently relapsed were reviewed. The age distribu-

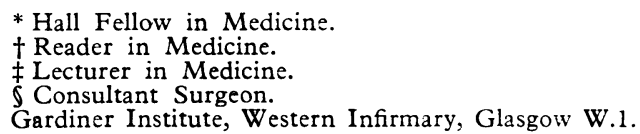

tion of the patients at the time of operation is shown in Table I. Sixty-one $(68 \%)$ of the thyroidectomies had been performed in the Western Infirmary, Glasgow, and 29 (32\%) in other hospitals. Thirty-three $(36.7 \%)$ of the operations were performed before $1950,43(47 \cdot 8 \%)$ during 1951-60, and 14 (15.5\%) during 1961-6.

TABLE I.-Age and Sex Distribution of 90 Patients who Relapsed after Thyroidectomy

\begin{tabular}{|c|c|c|c|c|c|c|}
\hline & & & 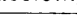 & & & \\
\hline & \multicolumn{6}{|c|}{ Age in Years } \\
\hline & -20 & $21-30$ & $31-40$ & $41-50$ & $51-60$ & $61-70$ \\
\hline $\begin{array}{l}\text { Male } \\
\text { Female }\end{array}$ & $\begin{array}{l}0 \\
4\end{array}$ & $\begin{array}{r}3 \\
16\end{array}$ & $\begin{array}{r}8 \\
31\end{array}$ & $\begin{array}{r}1 \\
20\end{array}$ & $\begin{array}{l}1 \\
5\end{array}$ & $\begin{array}{l}0 \\
1\end{array}$ \\
\hline
\end{tabular}

The time of relapse of thyrotoxicosis following the initial operation is shown in Fig. 1. Twelve (13.3\%) patients remained euthyroid for more than 15 years before relapse of thyrotoxicosis occurred

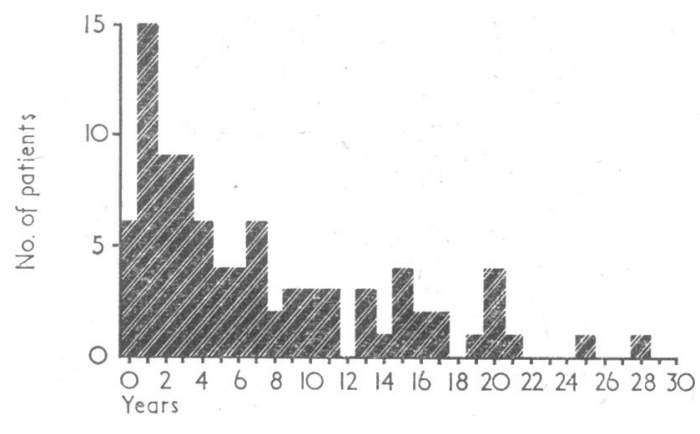

FIG. 1. - Time of relapse after thyroidectomy. 
Eighty-three presented with symptoms of recurrence and seven were found to be thyrotoxic when 84 patients treated by thyroidectomy for thyrotoxicosis in the Western Infirmary were reviewed (Roy et al., 1967). Fifty-four (65\%) had had symptoms for less than one year, $10(12 \%)$ for one to two years, and $5(6 \%)$ for more than two years. In $14(17 \%)$ the duration of symptoms was uncertain. Fifteen $(16.7 \%)$ of the patients had a family history of the disease, in four the affected relative was the mother, in one the father, in five a sister, in one a brother, in one a daughter, in two a paternal cousin, and in one a paternal grandmother. All the patients following recurrence attended the thyroid clinic at the Western Infirmary.

An empirical dosage prescription procedure as previously described by Crooks et al. (1960) was used when radioiodine was administered.

Assessment of Thyroid Status.-Thyroid status was assessed on clinical grounds (Wayne, 1960) and by laboratory tests, including standard radioiodine $\left({ }^{131} \mathrm{I}\right)$ tests with 5-hour and 48-hour thyroidal uptake, estimation of plasma levels of proteinbound radioiodine (P.B. ${ }^{131} \mathrm{I}$ ) at 48 hours (Wayne, 1960), the two-and-a-half-hour thyroidal radioiodine uptake and clearance and absolute uptake of iodine (A.I.U.) (Wayne et al., 1964), estimation of the serum P.B. ${ }^{127} \mathrm{I}$, the resin uptake of ${ }^{131} \mathrm{I}-$ labelled tri-iodothyronine, and the "free thyroxine" index (Clark and Horn, 1965).

Follow-up.-The patients were followed up at the thyroid clinic of the Western Infirmary until May 1968. Those who had not been followed regularly were requested by letter to attend for review. Fourteen patients were unable to attend. Three were not traced. In two information regarding their present state of health and thyroid status was obtained from their general practitioner, four had emigrated, and five had died -two from myocardial infarction, one following a subarachnoid haemorrhage, one with a neoplasm of the stomach, and one of carcinoma of the breast.

\section{Results}

Ten patients had a second operation, 20 received a course of antithyroid drugs, and 86 received one or more doses of radioiodine. The results of treatment are summarized in Fig. 2.

\section{Second Thyroidectomy}

Nine patients had a second operation as the first line of treatment. All subsequently relapsed, two within one year, three from one to two years, two from four to six years, and the remaining two from 6 to 10 years. One patient had a third operation, but after this had a further recurrence of thyrotoxicosis. Apart from the recurrence rate of $100 \%$ the incidence of complications was low. One developed a haematoma, one an abscess, and the patient who had three operations developed vocal cord paresis after the third operation. Following relapse three patients were treated with a full course of antithyroid drugs, after which all relapsed, and six received radioiodine. Of these, three became hypothyroid. One patient had a second thyroidectomy following a full course of antithyroid drugs, and this patient also relapsed. Six of the 10 patients who relapsed after a second operation had a positive family history of thyroid disease compared with $16.7 \%$ in the whole group $(P=0.001)$.

\section{Antithyroid Drugs}

After recurrence 17 patients were treated with antithyroid drugs for a minimum period of one year. Only two had remained euthyroid up to the time of follow-up (mean period euthyroid after stopping drugs 15 months). Fifteen relapsed. Of those who relapsed 11 were treated with radioiodine, one had a second operation, and three had a second course of drugs following which one again relapsed. At the time of review two patients were still receiving treatment. Nine of the 15 patients relapsed within three months and 12 within one year.

\section{Radioiodine}

Eighty-six patients received a therapeutic dose of radioiodine. Of these, 64 were treated immediately after the first recurrence, 12 following failure of treatment with antithyroid drugs, and 10 following recurrence after a second thyroidectomy. Fiftyone patients $(59.3 \%)$ required only one dose of radioiodine, 19 $(21.4 \%)$ received two doses, $10(11.6 \%)$ received three doses, and $6(7 \cdot 7 \%)$ required more than three doses. The dose in $\mathrm{mCi}$ administered and the distribution of hypothyroidism are shown in Table II. Forty-seven (54.7\%) patients became hypothyroid,

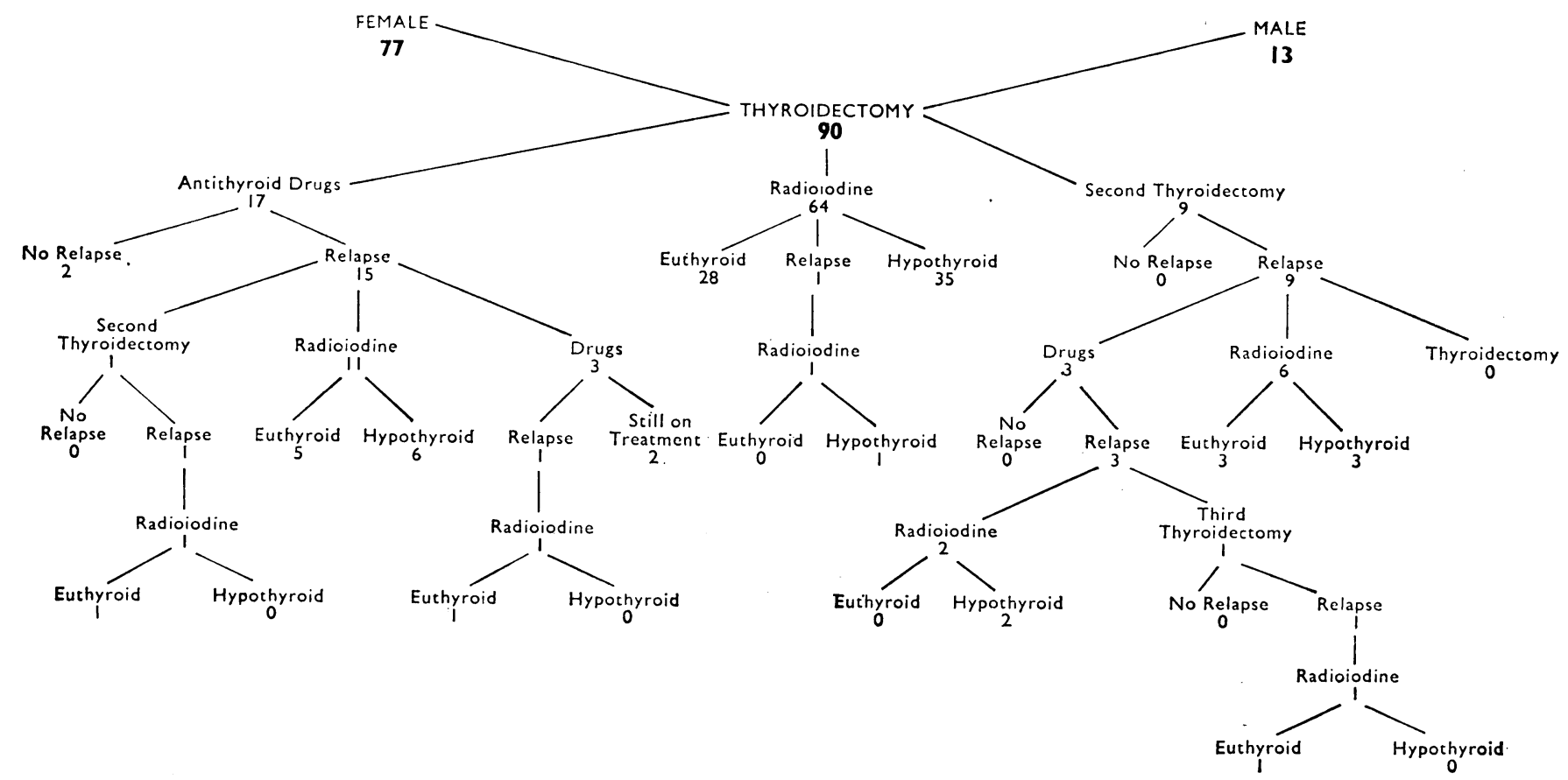

FIG. 2.-Results of treatment following relapse after thyroidectomy. 
the period of follow-up ranging from 1 to 10 years. One patient relapsed. Sixteen $(36 \%)$ of those who became hypothyroid received less than $10 \mathrm{mCi}$. Twenty-two (46.8\%) became hypothyroid within one year of treatment, while $11(23.4 \%)$ took over five years to become hypothyroid.

TABLE II.-Dose of Radioiodine Required to Control Recurrent Hyperthyroidism and Incidence of Hypothyroidism after Treatment

\begin{tabular}{|c|c|c|c|c|c|c|c|c|c|c|c|}
\hline & & \multicolumn{10}{|c|}{ Dose in $\mathrm{mCi}$} \\
\hline & & $<5$ & 5 & 6 & 7 & 8 & 9 & 10 & $11-15$ & $16-20$ & $>20$ \\
\hline $\begin{array}{l}\text { Euthyroid } \\
\text { Hypothyroid }\end{array}$ & $\because$ & $\begin{array}{l}0 \\
1\end{array}$ & $\begin{array}{l}5 \\
5\end{array}$ & $\begin{array}{l}8 \\
6\end{array}$ & $\begin{array}{l}6 \\
2\end{array}$ & $\begin{array}{l}3 \\
2\end{array}$ & $\begin{array}{l}1 \\
0\end{array}$ & $\begin{array}{l}3 \\
6\end{array}$ & $\begin{array}{r}3 \\
10\end{array}$ & $\begin{array}{l}3 \\
8\end{array}$ & $\begin{array}{l}7 \\
7\end{array}$ \\
\hline
\end{tabular}

Thirty-six $(54.7 \%)$ patients treated with radioiodine following the first thyroidectomy became hypothyroid compared with $5(50 \%)$ of the 10 patients treated with ${ }^{131} \mathrm{I}$ after a second thyroidectomy and $6(50 \%)$ of the 12 patients treated by ${ }^{131} \mathrm{I}$ after a full course of antithyroid drugs.

The test results confirming recurrent episodes of toxicity are shown in Table III, and are compared with a group of patients who remained euthyroid after thyroidectomy (Roy et al., 1967). Thyroid uptake measurements at 5 hours (Fig. 3), the plasma P.B. ${ }^{131} \mathrm{I}$ (Fig. 4), and the serum P.B. ${ }^{127}$ I (Fig. 5) are also shown and compared with the results of Roy et al. (1967) in euthyroid patients.

TABLE III.-Thyroid Function after Thyroidectomy

\begin{tabular}{|c|c|c|c|c|c|}
\hline \multirow[b]{2}{*}{ Test } & \multicolumn{2}{|c|}{$\begin{array}{l}\text { Euthyroid after } \\
\text { Thyroidectomy }\end{array}$} & \multicolumn{2}{|c|}{$\begin{array}{l}\text { Relapse after } \\
\text { Thyroidectomy }\end{array}$} & \multirow[b]{2}{*}{$\begin{array}{l}\text { Normal } \\
\text { Values }\end{array}$} \\
\hline & No. & $\begin{array}{c}\text { Roy et al. } \\
\text { (1967) } \\
\text { Mean } \\
\text { (S.E.M.) }\end{array}$ & No. & $\begin{array}{c}\text { Present } \\
\text { Series } \\
\text { Mean } \\
\text { (S.E.M.) }\end{array}$ & \\
\hline \multicolumn{6}{|l|}{ Radioiodineuptake ( $\%$ dose $)$} \\
\hline $\begin{array}{lll}21 \mathrm{hr} . & \ldots & \ldots\end{array}$ & 61 & $19 \cdot 4(1 \cdot 0)$ & 16 & $57 \cdot 74(4 \cdot 88)$ & $10-35$ \\
\hline & 29 & $26 \cdot 1(1 \cdot 7)$ & 54 & $75.99(2 \cdot 17)$ & $15-45$ \\
\hline $\begin{array}{l}48 \mathrm{hr} . \\
\text { Plasma } \mathrm{PB}\end{array}$ & 61 & $42 \cdot 1(1 \cdot 4)$ & 57 & $69 \cdot 70(1 \cdot 77)$ & $20-60$ \\
\hline per litre) & 58 & $0.47(0.08)$ & 51 & $1.64(0.14)$ & $0 \cdot 00-0 \cdot 20$ \\
\hline $\begin{array}{c}\text { Thyroid clearance }(\mathrm{ml} . / \\
\text { min.) }\end{array}$ & & $25 \cdot 0(1 \cdot 7)$ & 8 & $156.4(28.55)$ & \\
\hline $\operatorname{AIU}(\mu \mathrm{g} . / \mathrm{hr}.) \quad \ldots$ & 60 & $2 \cdot 0(0 \cdot 2)$ & 9 & $39.17(10.86)$ & $0 \cdot 5-6 \cdot 0$ \\
\hline $\mathrm{PB} 127 \mathrm{I}(\mu \mathrm{g} . / 100 \mathrm{ml}.) \quad \ldots$ & 65 & $5 \cdot 2(0 \cdot 2)$ & 43 & $10.97(0.45)$ & $3 \cdot 5-7 \cdot 5$ \\
\hline $\begin{array}{l}\mathrm{T}_{3} \text { resin uptake }\left({ }^{\circ},{ }^{\prime}\right) \\
\text { "Free thyroxine " }\end{array}$ & & & $\begin{array}{l}7 \\
7\end{array}$ & $\begin{array}{l}47 \cdot 11(3 \cdot 4) \\
11 \cdot 48(2 \cdot 3)\end{array}$ & $\begin{array}{c}25-35 \\
3-7\end{array}$ \\
\hline
\end{tabular}

The P.B.I. of 43 patients in whom the diagnosis of hypothyroidism was confirmed by P.B. ${ }^{127}$ I was $2 \cdot 03 \pm 0 \cdot 13$ (S.E.M.), the $\mathrm{T}_{3}$ resin uptake and "free thyroxine" index estimated in 14 patients were $25 \cdot 9 \pm 0.86$ and $1 \cdot 7 \pm 0.26$ respectively.

\section{Discussion}

The time of recurrence of thyrotoxicosis after thyroidectomy contrasts with the time of recurrence after cessation of antithyroid drugs. In the present series only $17 \%$ of those relapsing after treatment of thyrotoxicosis by thyroidectomy did so within the first year, compared with $70 \%$ of patients relapsing after antithyroid drugs (Hershman et al., 1966). Cattell et al. (1952) reported that $19(76 \%)$ of 25 patients whose thyrotoxicosis recurred after operation experienced the recurrence within three years of the initial operation. This supported the then current view that if patients remained symptom-free for a period of five years following operation, only a rare instance of recurrence would be found subsequently. In the present study only $54.5 \%$ of patients relapsed within five years after thyroidectomy. Hayles et al. (1959) reported that three patients had a recurrence more than 25 years after thyroidectomy.

Douglas and Kennie (1952) considered that relapse after thyroidectomy is usually relatively mild. This, however, is not confirmed by the present series, since the results of treatment by both reoperation and antithyroid drugs were unsatisfactory. Recently another patient, not included in the present series, has been referred for treatment following relapse after three thyroidectomies. Recurrence after a second operation was not related to one operator, as the operations were performed by six different surgeons. In view of the high incidence of relapse Cattell et al. (1952) recommended a more radical excision of remnants. Taylor and Painter (1962) showed that of 43 thyrotoxic patients treated by partial thyroidectomy the two who relapsed within a year had larger volumes of thyroid tissue left at operation than those who remained euthyroid. This study suggests that there is a group of patients with hyperthyroidism in whom thyroidectomy is not the treatment of choice. Moreover, a second operation is also not without risk, and Riddell (1965) regards such a procedure as "the cardinal folly" because of the high incidence of complications which is likely to ensue. In the present series one patient developed a recurrent laryngeal nerve palsy after a third operation.

Antithyroid drugs would also appear from the present series to be unsatisfactory in the treatment of recurrent thyrotoxicosis. Solomon et al. (1953), in reviewing data from eight clinics, found that the incidence of remission following cessation of antithyroid drug therapy was significantly greater for those patients with primary hyperthyroidism than for those with postoperative recurrence. Reveno and Rosenbaum (1964), on the other hand, reported a favourable response to antithyroid drugs in patients with recurrent hyperthyroidism though the
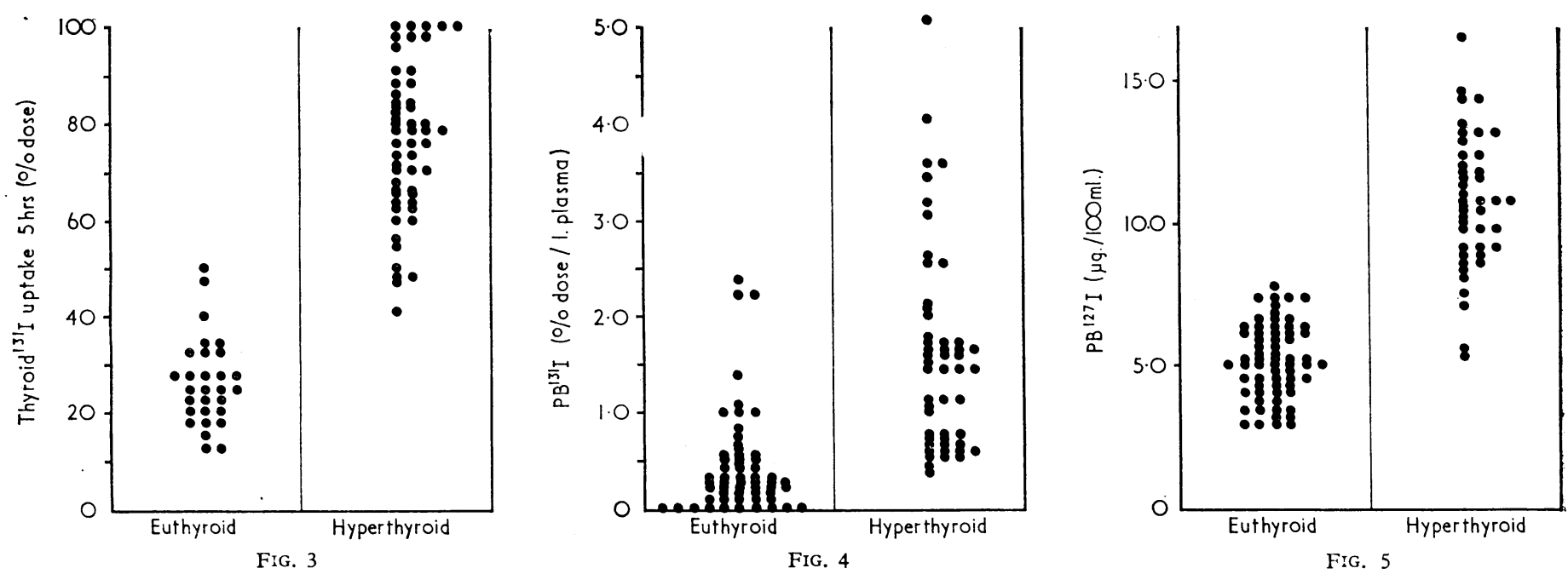

FIG. 3.-Thyroid radioiodine uptake measurements at 5 hours in patients euthyroid and hyperthyroid after thyroidectomy. Fig. 4.-P.B. 131 I values at 48 hours in patients euthyroid and hyperthyroid after thyroid ectomy. Fig. 5.-Serum P.B. ${ }^{127}$ I in patients euthyroid and hyperthyroid. after thyroidectomy. 
period of drug treatment required was longer. Hershman et al. (1966) found no significant difference in the incidence of remission in the two groups.

The results of treatment with radioiodine were more satisfactory and compared favourably with those reported by Green and Wilson (1964), though the proportion requiring only one dose was less than that reported in other series (MacGregor, 1957 ; Blomfield et al., 1959 ; McGirr et al., 1964 ; Staffurth and Young, 1967). Blomfield et al. (1959) found that the response to radioiodine was similar in patients with recurrent thyrotoxicosis and those with primary hyperthyroidism. The incidence of hypothyroidism would appear to be greater, since Greig (1966) reported an incidence of $41 \%$ in patients followed up for one to eight years at this clinic. The incidence of hypothyroidism reported in other series is also lower (Beling and Einhorn, 1961 ; Green and Wilson, 1964 ; Dunn and Chapman, 1964 ; McGirr et al., 1964), though Nofal et al. (1966) reported an incidence of $51 \%$ in patients treated with radioiodine and followed for 1 to 16 years. Dunn and Chapman (1964) found that the incidence of hypothyroidism was significantly greater in those patients who had had a previous thyroidectomy. Sensitivity to radioiodine in patients with recurrent hyperthyroidism may be due in part to increased radiosensitivity and to difficulties in estimating the size of the thyroid remnant (Dunn and Chapman, 1964). Radioiodine would appear to be the treatment of choice in patients who relapse after thyroidectomy provided that adequate follow-up is undertaken. In the present series those who did not receive ${ }^{131}$ I initially were subjected to prolonged periods of ill-health and fruitless treatment.

It has been shown that in euthyroid patients following thyroidectomy the P.B. ${ }^{131}$ I may be raised owing to a low intrathyroidal iodine pool, and the thyroidal radioiodine uptake may also be raised owing to a small extrathyroidal iodine pool (Koutras et al., 1961 ; Roy et al., 1967). When the test results in the present series are compared with those in euthyroid patients after thyroidectomy (Roy et al., 1967), the P.B. ${ }^{131}$ I provides poor separation between euthyroid and thyrotoxic patients. Thyroid uptake measurements at five hours and estimation of the serum P.B. ${ }^{127}$ I are, however, of greatzr value in diagnosing post-thyroidectomy recurrences.

REFERENCES

Beling, U., and Einhorn, J. (1961). Acta Radiologica, 56, 275.

Blomfield, G. W., Eckert, H., Fisher, M., Miller, H., Munro, D. S., and Wilson, G. M. (1959). British Medical fournal, 1, 63.

attell, R. B., Alford, A. W., and Bartels, E. C. (1952). Fournal of Clinical Endocrinology and Metabolism, 12, 1389.

Clark, F., and Horn, D. B. (1965). Fournal of Clinical Endocrinology and Metabolism, 25, 39

Crooks, J., Buchanan, W. W., and Wayne, E. J. (1960). British Medical Fournal, 1, 151.

Douglas, D., and Kennie, A. T. (1952). British Medical fournal, 2, 1387. Dunn, J. T., and Chapman, E. M. (1964). New England fournal of Medicine, 271, 1037.

Green, M., and Wilson, G. M. (1964). British Medical fournal, 1, 1005.

Green, M., and Wilson, G. M. (1964). British Medical fou

Greig, W. R. (1966). Scottish Medical fournal, 11, 307. y. B. B., Kennedy, R. L. J., Beahrs, O. H., and Woolner, L. B. (1959). Fournal of Clinical Endocrinology and Metabolism, 19, 138. ershman, J. M., Givens, J. R., Cassidy, C. E., and Astwood, E. B. (1966). Fournal of Clinical Endocrinology and Metabolism, 26, 803.

Koutras, D. A., Alexander, W. D., Buchanan, W. W., Crooks, J., and Wayne, E. J. (1961). Acta Endocrinologica, 37, 597.

McGirr, E. M., Thomson, J. A., and Murray, I. P. C. (1964). Scottish Medical fournal, 9, 505.

MacGregor, A. G. (1957). British Medical fournal, 1, 492.

Nofal, M. M., Beierwaltes, W. H., and Patno, M. E. (1966). Fournal of the American Medical Association, 197, 605.

Reveno, W. S., and Rosenbaum, H. (1964). Annals of Internal Medicine, 60, 982 .

Riddell, V. (1965). British fournal of Surgery, 52, 721.

Roy, A. D., Allan, J., and Harden, R. McG. (1967). Lancet, 2, 684.

Solomon, D. H., Beck, J. C., VanderLaan, W. P., and Astwood, E. B. (1953). Journal of the American Medical Association, 152, 201

Staffurth, J. S., and Young, J. (1967). Fournal of Clinical Endocrinology and Metabolism, 27, 1062 .

Taylor, G. W., and Painter, N. S. (1962). Lancet, 1, 287.

Wayne, E. J. (1960). British Medical fournal, 1, 1, 78.

Wayne, E. J., Koutras, D. A., and Alexander, W. D. (1964). Clinical Aspects of Iodine Metabolism. Oxford, Blackwell Scientific Publications.

\title{
Results of Treatment of Thyrotoxicosis following Relapse after Antithyroid Drug Therapy
}

\author{
D. G. MCLARTY;* M.B., CH.B. ; W. D. ALEXANDER, $\dagger$ M.D., F.R.C.P.ED. ; R. MCG. HARDEN, $\ddagger$ M.R.C.P.GLASG. \\ D. H. CLARK,§ M.D., CH.M., F.R.C.S.
}

British Medical fournal, 1969, 3, 203-205

\begin{abstract}
Summary: One hundred and thirty patients who relapsed after a full course of treatment with antithyroid drugs have been reviewed. Of 22 patients receiving a second course of antithyroid drugs, $17(77 \%)$ relapsed. In contrast, only 2 out of 44 patients treated by surgery relapsed and seven became hypothyroid. Nevertheless, local complications, in particular parathyroid insufficiency, were especially common in this group. Eighty patients received radioiodine, $11(14 \%)$ requiring more than three doses before finally being rendered euthyroid. Postradiation hypothyroidism developed in $39(49 \%)$ patients.
\end{abstract}

- Hall Fellow in Medicine.

$t$ Reader in Medicine.

$\$$ Lecturer in Medicine.

Gardiner Institute, Western Infirmary, Glasgow W.1.

\section{Introduction}

Since antithyroid drugs were first introduced numerous reports of their effectiveness have been published. Little attention, however, has been paid to the prognosis for those patients in whom thyrotoxicosis recurs after discontinuation of antithyroid drug therapy. In this study 130 thyrotoxic patients who relapsed after treatment with antithyroid drugs have been followed up.

\section{Methods}

Patients Studied.-The age and sex of the patients studied is shown in Table $I$. Of the 130 patients, 102 were treated initially in the Western Infirmary, Glasgow, and 28 in other hospitals. All had received antithyroid drugs for a minimum 